\title{
Efficacy of Monochromatic Infrared Energy on Pressure Ulcer Healing
}

\author{
AHMED M. ELANAY, M.Sc.*; ADEL A. NOSEIR, Ph.D.*; MAHMOUD A. HEMIDA, M.D.** and \\ ASMAA E. FAWZY, Ph.D.* \\ The Department of Physical Therapy for Surgery, Faculty of Physical Therapy, Cairo University, Giza* and \\ The Department of Surgery, Faculty of Medicine, Alexandria University**, Egypt
}

\begin{abstract}
Background: Monochromatic infrared energy has a lot of uses and in this study I use it to help patients with pressure ulcer in healing of their wounds.

Aim of Study: To determine the effect of monochromatic infrared energy therapy on patients with pressure ulcers.

Material and Methods: Measuring wound volume with saline and sterilized syringe.

Thirty patients (19 males and 11 females) with ages ranging from $30-75$ years suffering from pressure ulcer participated in this study. They were selected randomly from Medical Research Insistute and Sharq El-Madina Hospitals during the year 2018, they were randomly divided into 2 equal groups in number, one study Group (A) and a control one (B). The study Group (A) who received the monochromatic infrared energy for 30 minutes every session, application was done 5 times per week for 6 weeks as a total period of treatment in addition to their medical treatment, the control Group (B) who not received the monochromatic infrared energy but they just received standard medical treatment. Measurements were conducted before starting the treatment as a first record and at the end of the 6 weeks of treatment as a second (final) record.
\end{abstract}

Results: Result showed that the polarized light therapy was effective and fruitful in increasing wound healing in pressure ulcer as evidenced by the highly significant decrease in the wound volume.

Conclusion: Monochromatic infrared enenrgy therapy is beneficial in improving wound healing in pressure ulcer.

Key Words: Monochromatic infrared enenrgy therapy - Pressure ulcer-Wound healing.

\section{Introduction}

PRESSURE ulcer defined as any localized lesion to the skin and/or underlying tissue caused by unrelieved pressure, resulting in damage of under-

Correspondence to: Dr. Ahmed M. Elanay, The Department of Physical Therapy for Surgery, Faculty of Physical Therapy, Cairo University, Giza, Egypt lying tissue are acknowledged to be a clinical challenge for both the clinician and the patient [6]

Preventing pressure injury remains a complex clinical challenge in acute health care facilities. Prevalence rates vary, with the highest rates among geriatric and intensive care patients, and the lowest rates among those receiving psychiatric care. Pressure ulcers often have negative consequences for patients and may add considerably to the cost of an inpatient stay [10].

All mechanical or electrical modalities used for wound healing supposed to introduce energy to the affected area and activate certain processes inside the cell to trigger some sequence of reactions. It would be impossible to assume that one treatment or modality can generate all positive needed results. The future research should focus on helping clinician to decide which modality is the optimum to use for how long and in what sequence to achieve complete healing in diabetic wounds [4].

\section{Material and Methods}

In Sharq El-Madina and Medical Research Institute Hospitals for 6 weeks, the patients were randomly assigned into two equal groups (15 patients of each group) (study and control groups). Group (A): The study group received Monochromatic infrared energy, in addition to the standard medical treatment the application of the Monochromatic infrared energy 30min, 5 times per week and for six weeks, Group (B): The controlled group received only standard medical treatment for pressure ulcer.

\section{Inclusive criteria included:}

Patients were of both sexes (19 males and 11 females). Age of the patients ranged from 30 to 75 
years. The lesion is pressure ulcers grade II or III according to European Pressure Ulcer Advisory Panel Grading System.

\section{Exclusive criteria included:}

- Patients with malignancies or receiving radiotherapy or chemotherapy.

- Serious or terminal malignancy or terminal illness.

- Pacemaker.

- Photosensitivity or sensitivity of electromagnetic radiation.

- Necrotic tissue with scar if debridement is not performed.

- Untreated osteomyelitis within the vicinity of wound.

- Fistula to an organ or body cavity within the vicinity of the wound.

- Recent therapy with immunosuppressant or anticonvulsant drugs.

- Concurrent participation in another clinical study.

- Patients suffering from psychological problems.

\section{Ethics:}

The protocol of this study was approved by the Ethical Committees of the Faculty of Physical Therapy (Cairo University, Egypt). Every patient applied informed consent before starting the study. All participants were informed about the nature and the effect of the treatment and measurement devices. The patients were also instructed to report any side effects during the treatment sessions.

\section{Measurements:}

A simple technique to measure wound volume was described for use on wounds that were gravity dependent (perpendicular to the line of gravity). Saline from a syringe was injected into the wound cavity until it was filled. The saline left in the syringe was subtracted from the starting amount which indicated the volume in cubic. The wound volume measurements were evaluated before beginning of the treatment and after six weeks of treatment [5].

\section{Treatment procedures:}

Group A (experimental group) subjects were the patient was placed in a comfortable position such as long sitting on the bed. The places on which the electrodes were applied should be showered and cleaned with mild saline solution. The electrode pads were wrapped with a clear plastic wrapping to prevent contamination. The pads were placed with direct contact with the ulcer and the cables were connected to the base unit. The device was switched on, after completing the treatment session of thirty minutes the device was switched off and the pads were removed.

Group B (control group) were received only standard medical treatment for pressure ulcer.

\section{Statistical procedures:}

Descriptive statistics and $t$-test were conducted for comparison of subject characteristics between both groups. $t$-test was conducted to compare mean values of hair count between both groups. Paired $t$-test was conducted to compare between pre and post-treatment mean values of hair count in each group. Mann-Whitney U-test was conducted for comparison of median values of 7-point assessment scale between both groups. Wilcoxon signed ranks test was conducted for comparison of median values of 7-point assessment scale between pre and posttreatment in each group. The level of significance for all statistical tests was set at $p<0.05$. The Statistical Package for Social Science (SPSS) will be utilized for data analysis [7].

\section{Results}

\section{I-Pre-treatment mean values of wound volume of both groups (study and control):}

The mean, SD wound volume pre-treatment of study group was $17.41 \pm 4.88 \mathrm{~cm}^{3}$ and that of control group was $17.42 \pm 4.66 \mathrm{~cm}^{3}$. The mean difference between both groups was $0.1 \mathrm{~cm}^{3}$. There was no significant difference in the wound volume between study and control group.

\section{II-Pre and post-treatment mean values of wound volume of the study Group A:}

The mean SD wound volume pre-treatment of study group was $17.41 \pm 4.88 \mathrm{~cm}$ and the post treatment was $8.27 \pm 3.28 \mathrm{~cm}^{3}$. The mean difference between pre and post-treatment was $10.80 \mathrm{~cm}^{3}$ There was a significant decrease in wound volume in the study group post-treatment compared with pre-treatment.

\section{III- Pre and post-treatment mean values of wound volume of control Group B.}

The mean SD wound volume pre-treatment of control group was $17.42 \pm 4,66 \mathrm{~cm}$ and that posttreatment was $17.26 \pm 4.86 \mathrm{~cm}$. The mean difference between pre and post-treatment was $0.1 \mathrm{~cm}$. There was a significant decrease in the wound volume in the control group post-treatment compared with pre-treatment. 


\section{IV-Post-treatment mean values of wound volme of both groups (study and control):}

The mean wound volume post-treatment of study group was $8.27 \pm 3.28 \mathrm{~cm}^{3}$ and that of control group was $17.26 \pm 4.86 \mathrm{~cm}$. The mean difference between both groups was $-10.60 \mathrm{~cm}^{3}$. There was a significant decrease in the wound volume in the study group compared with control group posttreatment.

Table (1): Pre-treatment mean values of wound volume of both groups (study and control).

\begin{tabular}{|c|c|c|c|c|}
\hline UVM & $\begin{array}{l}\text { Group I } \\
(\mathrm{n}=15)\end{array}$ & $\begin{array}{c}\text { Group II } \\
(\mathrm{n}=15)\end{array}$ & $\begin{array}{l}\text { Test of } \\
\text { sig. }\end{array}$ & $p$ \\
\hline \multicolumn{5}{|l|}{ Before: } \\
\hline Min.-max. & $9.70-22.0$ & $10.80-21.80$ & $t=$ & 0.995 \\
\hline Mean-SD. & $17.41 \pm 4.88$ & $17.42 \pm 4.66$ & 0.006 & \\
\hline Median & 19.80 & 19.70 & & \\
\hline
\end{tabular}

$t:$ Student $t$-test.

$p_{*}: p$-value for comparing between the studied groups.

: Statistically significant at $p \leq 0.05$.

Table (2): Comparison between the two studied periods according to UVM in study group.

\begin{tabular}{lllcc}
\hline UVM & Before & After & $t$ & \multicolumn{1}{c}{$p$} \\
\hline Min.-max. & $9.70-22.0$ & $3.50-13.0$ & $15.363^{*}$ & $<0.001^{*}$ \\
Mean-SD. & $17.41 \pm 4.88$ & $8.27 \pm 3.28$ & & \\
Median & 19.80 & 9.0 & & \\
\hline
\end{tabular}

$t:$ Paired $t$-test.

$p_{*}: p$-value for comparing between before and after.

: Statistically significant at $p \leq 0.05$.

Table (3): Comparison between the two studied periods according to UVM in control group.

\begin{tabular}{lllcc}
\hline UVM & Before & After & $t$ & $p$ \\
\hline Min.-max. & $10.80-21.80$ & $9.60-21.70$ & 1.550 & 0.143 \\
Mean-SD. & $17.42 \pm 4.66$ & $17.26 \pm 4.86$ & & \\
Median & 19.70 & 19.60 & & \\
\hline
\end{tabular}

$t:$ Paired $t$-test.

$p: p$-value for comparing between before and after.

: Statistically significant at $p \leq 0.05$.

Table (4): Comparison between post-treatment mean values of wound volume of both groups (study and control).

\begin{tabular}{lllll}
\hline UVM & $\begin{array}{l}\text { Group I } \\
(\mathrm{n}=15)\end{array}$ & $\begin{array}{l}\text { Group II } \\
(\mathrm{n}=15)\end{array}$ & $\begin{array}{c}\text { Test of } \\
\text { sig. }\end{array}$ & $p$ \\
\hline After: & & & & \\
Min.-max. & $3.50-13.0$ & $9.60-21.70$ & $t=$ & $<0.001 *$ \\
Mean-SD. & $8.27 \pm 3.28$ & $17.26 \pm 4.86$ & $5.941 *$ & \\
Median & 9.0 & 19.60 & & \\
\hline
\end{tabular}

$t$ : Student $t$-test.

$p_{*}: p$-value for comparing between the studied groups.

: Statistically significant at $p \leq 0.05$.

\section{Discussion}

The purpose of this study was to investigate the efficacy of mono-chromatic infrared energy on pressure ulcer.

This present study had deal with thirty patients who had pressure ulcer. They were randomly divided into two equal groups, study group (Monochromatic infrared energy plus standard medical treatment) and control group (standard medical treatment only).

They ranged in age from 30-75 years. They were classified randomly into two equal number (study and control). They were selected from Medical Research Institute Hospital and Sharq ElMadina Hospital. All patients in two groups of the study were receiving the same medical treatment.

All patients in both groups were assessed before and after 6 weeks treatment program by measuring wound volume by srerelized syringe and saline.

The statistical analysis of the study results showed that the mean \& SD of the MIRE therapy group pre-treatment were $\left(17.41 \pm 4.88 \mathrm{~cm}^{3}\right)$.

There was a significant decrease in wound volume after ${ }_{3} 6$ weeks at the end of treatment to $\left(8.27 \pm 3.28 \mathrm{~cm}^{3}\right)$. Regarding standard medical treatment group the mean \& SD pre-treatment were $(17.42 \pm 4.66 \mathrm{~cm})$. There was a significant decrease in wound volume after 6 weeks at the end of treatment to $(17.26 \pm 4.86 \mathrm{~cm})$.

One of the interesting results of current study was the presence of significance difference and improvement of all scores and mean values of wound volume before and after treatment within MIRE therapy group compared to standard medical treatment group after completion of sessions.

The incidence of pressure ulcers varies widely by hospitalized population. In acute care hospitals the incidence ranges from 1 to $29 \%$, with prevalence of 3 to $69 \%$ within geriatric subpopulation, incidence rates as high as $24 \%$ with prevalence of $17,4 \%$. These conditions are responsible for physical, social and vocational costs, as well as the economic cost of treating ulcer. A total cost of pressure ulcer treatment in the USA, for example, ranges from $\$ 1,3$ to $\$ 6$ billion annually [3]

Pressure ulcers are a prevalent and potentially serious medical problem, particularly among population whose skin is more prone to breakdown, as elderly injuries and other co-morbidities as diabetes. Pressure ulcers occur in all age groups 
from children to young adults from middle age to elderly. In the sitting dependent $75 \%$ of all patients will experience breakdown and by far the most common sites for these pressure ulcers are the ischium, coccyx and sacrum. Patients will have a recurrence of the same skin breakdown. Recent reports in plastic surgery journals showed that failure rates for flap surgeries ranged from $76 \%$ to $91 \%$. Therefore pressure ulcers are a costly and recurring problem [1].

Pressure ulcers are areas of injured skin and tissue. They are usually caused by sitting or lying in one position for too long. This puts pressure on certain areas of the body. The pressure can reduce the blood supply to the skin and the tissues under the skin. When a change in position doesn't occur often enough and the blood supply gets too low a sore may form. Pressure sores are also called bed sores, pressure ulcers and decubitus ulcers [2]

Monochromatic infrared energy has been in use since 1994 when it was cleared for marketing by the Food and Drug Administration (FDA) for increasing local circulation and for reducing pain. The proposed mechanism of action for MIRE is to increase the microcirculation of the tissues under the diodes as a result of hemoglobin absorbing the infrared wavelength and releasing small amounts of Nitric Oxide (NO) in the blood vessels. This is believed by some to increase endothelial cell formation of NO, a powerful vasodilator and angiogenesis mediator. Angiogenesis and vasodilatation increase circulating oxygen levels in the treated tissues. Scanning Laser Doppler has been used in case studies demonstrating improved tissue perfusion, or microcirculation, in the tissues receiving MIRE treatment [11]

Monochromatic infrared energy therapy is a therapy that utilizes infrared light therapy through contact with the skin. This therapy may also be referred to as infrared therapy, near-infrared light therapy, and infrared light treatment. It is also known as monochromatic, near-infrared photo energy (MIRETM) (Anodyne Therapy LLC, Tampa, FL). The Anodyne ${ }^{\circledR}$ Therapy System (ATS) (Anodyne Therapy LLC, Tampa, FL) is one type of devices that utilizes MIRE. With Anodyne devices, light is emitted by an array of 60 superluminous gallium aluminum diodes located on a flexible pad. According to the manufacturer website the mechanism of action is a combination of topical heat and an increased local release of nitric oxide with use of wavelength $(890 \mathrm{~nm})$ of near infrared light energy [9].
The Anodyne Professional Therapy System is a MIRE device that received marketing clearance from the U.S. Food and Drug Administration (FDA) in 1994 through the $510(\mathrm{k})$ process. Wound healing involves a highly complex set of physiological processes regulated by many different cellular and humeral factors; MIRE therapy stimulate the endogenous purification by removal of infectious microorganisms and cell debris via the following; increasing stimulation of macrophages, increasing bacterial phagocytosis activity and bacterial phagocytosis capacity by increasing formation of the scavenger cells, increasing stimulation of neutrophils, increasing number of neutrophils and phagocytosis activity [8]

\section{References}

1- BABU M.M. and WELLS A.P.: "Dermal-epidermal communication in wound healing"Wounds, 13 (5): Pp. 183 9, 2009.

2- BERG W.S., TRANEORTH C.V. and GUNNARSSON A.L.: "A method for measuring pressure sore". Lancet; 1445-6, 2008

3- CONOR K.: "Physical medicine and rehabilitation: Principles and practice". 4 th ed. Philaldelphia: Lippincott willams and Willkins; p. 1605-18, 2005.

4- ENNIS W.J., LEE C. and MENSES P.: "A Biomechanical approach to wound healing through the use of modalities" Clinics In Dermatology, 25: 63-72, 2007.

5- ENOCH S.E. and HADING K.A.: "Wound bed preparation: The science the removal of brriers to healing" Wounds, Vol.15, No., pp. 212-29, 2003.

6- GUPTA S., BAHARESTANI M. and BARANOSKI S. "Guidelines for managing pressure ulcers with negative pressure wound therapy". Adv. Skin Wound Care, 17 (2): 1-16, 2004.

7- INDRAYAN A.: "Medical biostatistics, Third Edition (Champan \& Hall/CRC Biostatistics Series) ${ }^{3 \text { rd }}$ Ed Chapter (15); 537-601, 2013.

8- THOMAS S.: "An introduction to the use of vacuum assisted closure". (Online) available at http:/www. Worldwidwwounds.com/2001/may/Thomas/Vacuum-AssistedClosure.html, 2001.

9- THOMASSON T.L.: "Effect of skin-contact monochromatic infrared irradiation on tendonitis, capsulitis, and myofascial pain. Journal Neural Orthopaedic Medical Surgery, 16: 242-5, 1996.

10- WEBSTER J., COLEMAN K., MUDGE A. and MARQUART L.: "Pressure Ulcers: Effectiveness of riskassessment tools. A randomized controlled trial". BMJ, 20: 297-306, 2011.

11- VOLKERT W.A., HASSAN A.G. and SMOCK V.L.: "Effectiveness of monochromatic infrared photo energy and physical therapy for alterations in tissue composition a preliminary, multi-center study". Physical occupational therapy for geriatric, 2005. 


\section{فاعلية طاقة الآشعة تحت الحمراء آحادية اللون فى علاج قرح الفراش}

السستخلص: تطبيق الآثعة تحت الحمراء آحادية اللون على مرضى قرحة الفراش مما يحفز إلتتام قرحة الفراش. الهدف: لمعرفة ناعلية طاقة الآشعة تحت الحمراء آحادية اللون فى علاج قرح الفراش.

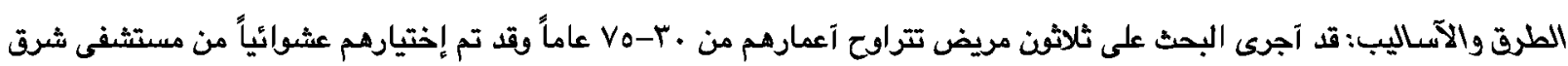

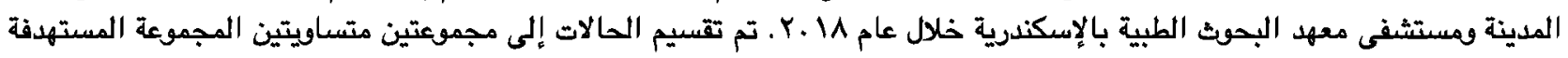

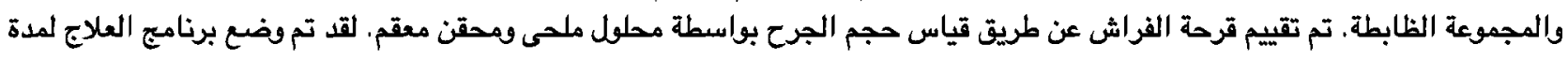
7 آسابيع.

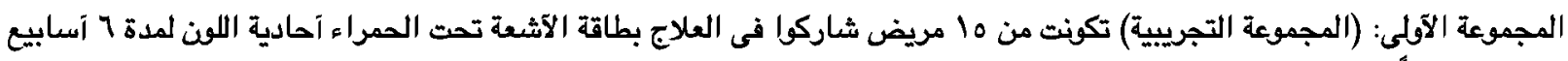

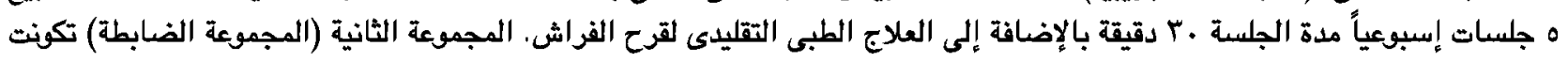

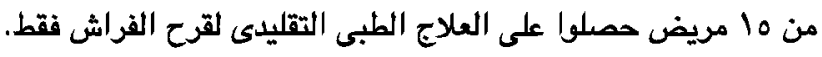

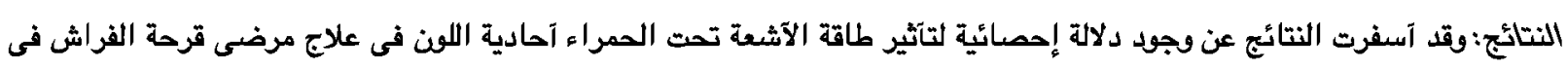
المجموعة التجريبية فى مقابل المجموعة الضابطة. الخلاصة: من هذه النتائج يمكن الإستدلال آن طاقة الآشعة تحت الحمراء آحادية اللون لها تآثير مباشر على شفاء قرح القراش. 